\title{
A Conscious Stratagem or Garbled Memory? A Few Notes to the Anonymous Report on the Avar Siege of Constantinople Preserved in the Historia Syntomos of Patriarch Nikephoros
}

\author{
Martin Hurbanič
}

\begin{abstract}
The anonymous report on the Avar siege of Constantinople in 626 preserved in the Historia Syntomos of patriarch Nikephoros from the $9^{\text {th }}$ century has long been considered as a kind of supplement to the contemporary sources about the siege. In this paper, I will try to analyze selected motives in this report and compare them not only with information from contemporary sources, but also with the conclusions I presented in my previous studies dedicated to the topography of the Avar siege of Constantinople.
\end{abstract}

\section{Keywords}

Patriarch Nikephoros; Avars; Slavs; siege of Constantinople in 626; Blachernae

The research for this paper was financially supported by VEGA 1/0427/14. The finalisation of this paper was supported by internal grant of the Faculty of Philosophy of Comenius University (Bratislava) No. FG08/2017. 
It is commonly known that the Historia Syntomos of Patriarch Nikephoros from the end of the $8^{\text {th }}$ century contains a relatively short but quite often debated report on the Avar attack of Constantinople in $626 .{ }^{1}$ Contemporary historians usually consider it as a kind of supplement to the primary sources, especially to lost folio in the only extant manuscript of Chronicon Paschale, which contained detailed information on the most decisive day of this attack. ${ }^{2}$

The authors with a more critical view move it into position between history and tradition. ${ }^{3}$ Nevertheless, the memory of the first great siege of Constantinople was held in the Byzantine chronographical tradition in a very concise form. ${ }^{4}$ The late Byzantine chroniclers obviously did not have access to the official account of the Avar siege preserved in the Chronicon Paschale. Instead, they took their information from other sources, including the Historia Syntomos of Patriarch Nikephoros. ${ }^{5}$

The above statement, however, does not apply to the core of Nikephoros' report on the Avar siege - i.e. the attack of the Slavic monoxyla and the subsequent stratagem of patrikios and magister Bonos. The testimony sounds somewhat contradictory - it

1 Nikeph. (1990: c. 13, pp. 58-60). On his Historia Syntomos see esp. Mango (1986: pp. 539-552); Mango (1990: pp. 1-31); Howard-Johnston (2010: pp. 237-267). In this connection, see also Moravcsik (1956: pp. 456-459); Hunger (1978: pp. 334-337); Чичуров (1980: pp. 145-150); Speck (1988: pp. 195-211).

2 In this context, see e.g. Barišić (1954: p. 387); Stratos (1968: p. 190); Grumel (1964: pp. 218, 221); Waldmüller (1976: pp. 273-274); Tsangadas (1980: p. 84); Van Dieten (1985: pp. 169-171); Howard-Johnston (1995: pp. 140-141); Howard-Johnston (2010: p. 254). For a debate on the siege of Constantinople in 626 see, among others, Pernice (1905: pp. 138-149); Barišić (1954: pp. 371-395); Stratos (1967: pp. 370-376); Stratos (1968: pp. 173-196); Waldmüller (1976: pp. 265-283); Havlíková (1979: pp. 126-136); Tsangadas (1980: pp. 80-106); Speck (1980); Van Dieten (1985: pp. 149-178); Speck (1986: pp. 209-227); Speck (1987: pp. 371-402); Pohl (1988: pp. 248-255); Боровский (1988: pp. 114-119); Howard-Johnston (1995:

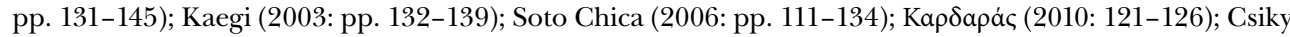
(2012: pp. 165-183); Tбı $\alpha \pi \lambda \varepsilon ́ \varsigma$ (2015: pp. 79-97) and Kaçar (2017: pp. 171-200). See also my contributions: Hurbanič (2009); Hurbanič (2010); Hurbanič (2012: pp. 15-24); Hurbanič (2015: pp. 211-220) and Hurbanič (2016).

3 Pohl (1988: p. 253, see also p. 428, n. 53). The core of Nikephoros' version concerning the stratagem of magister Bonos was also rejected by Paul Speck, who drew attention to a broad array of logical inconsistencies and interpretation problems in this report. What is more problematic is his speculations concerning the topography of fortifications in Constantinople. Likewise, the statement that the so-called wall of Heraclius, which crossed the remaining part of the city along the Golden Horn, was already constructed at the time of the Avar siege. See Speck (1988: pp. 298-316).

4 For an overview of the later chronicles containing an account of the Avar siege, see Barišič (1954: pp. 372377); Szádeczky-Kardoss (1998: pp. 171-208, together with other sources); Hurbanič (2010: pp. 107-113).

5 The other main source is the Chronography of Theophanes. Cf. Theoph. (1883: pp. 315.7-315.14 and 316.1627). Its report on Avar siege was taken directly by Georgios Kedrenos. Cf. Georg. Kedr. (1838: pp. 727.11727.17). In addition, Kedrenos preserved a unique legendary story about the miraculous revelation of the Virgin Mary before the walls of Blachernae. On the other side, the account of Avar siege preserved by Nikephoros was probably a source of some information for the monk and chronicler Georgios Monachos Hamartolos. Cf. Georg. Mon. (1904: pp. 670.18-671.5). He was in turn a source for another chronicler Symeon Logothetes. Cf. Sym. Logoth. (2006: pp. 109.7, 159.59-160.66). Other references to the Avar siege are recorded as short notices where the original source is difficult to prove. Cf. Chron. Brux. (1894: p. 29); Jo. Zon. (1897: pp. 208.17-209.7); Synops. chron. (1894: p. 108) and Theod. Skut. (2015: c. 199, p. 122). An exception is the chronicle of Constantine Manasses from the $12^{\text {th }}$ century, who apparently used one of the copies of the Pisides' contemporary poem Bellum Avaricum. Cf. Const. Manass. (1996: v. 3682-3731, pp. 200-203). 
had no reception in the later Byzantine sources and, as already indicated, the current historiography is not unanimous regarding its importance. What historical value should be attributed to it? In other words - it is more likely either to be a supplement of contemporary sources, or to represent more of a reflection of tradition and a subsequent interpretation of events. When trying to answer this question, our primary perspective is the informative value of this report in terms of reconstructing the events of the Avar siege. It is also due to this fact that a partial analysis of this passage is necessary. Indeed, such a procedure is not completely new in historiography; however, it must be noted that a detailed analysis of the report was only attempted by a few scholars, whereas two of them (P. Speck and J. L. Van Dieten) arrived at completely opposing conclusions. ${ }^{6}$

\section{The nature of Nikephoros' report and the question of sources}

It is not clear what sources Nikephoros used when describing the Avar attack, but it can be stated with certainty that he did not refer to any contemporary report. For the first part of Historia Syntomos reaching to AD 641 - with the exception of Chapter 1 - he had only one source available - whether it was the anonymous Constantinopolitan Chronicle, proposed by majority of authors, or, rather a historical pamphlet written by the patriarch Pyrrhos, or by his apologist, as recently proposed by C. Zuckerman, is difficult to prove. ${ }^{7}$ More importantly, however, the anonymous author referenced by Nikephoros had limited knowledge of the matters discussed. Much of what he recorded is a compilation of simple entries and trivial stories that circulated in the capital city. That partly refers also to the presented version of the Avar attack. Undoubtedly, it is an unofficial, and probably orally transmitted report, written about fifteen or twenty years after the event, or even later.

What is revealed on the very attack is that siege engines (wooden towers and tortoises) were prepared against the city, but were destroyed by the power of God. It is only the decisive battle on the tenth day that is described in detail. For greater clarity, we will quote the original in its entirety:

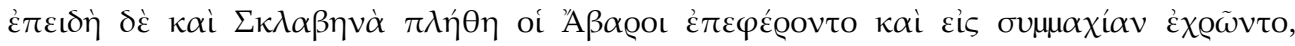

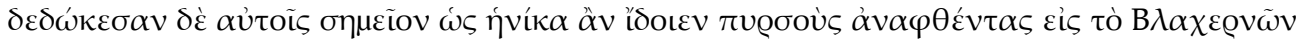

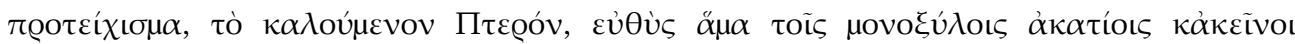

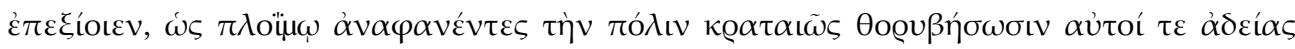

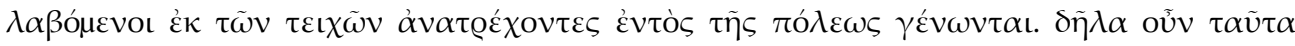

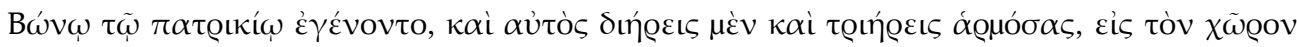

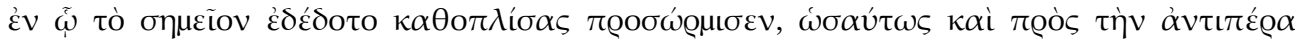

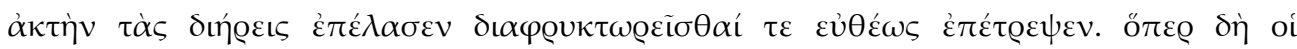

6 Speck (1980: pp. 92-93, n. 106); Van Dieten (1985: pp. 168-171) and Speck (1988: pp. 298-316).

7 Cf. Mango (1986: p. 543); Mango (1990: p. 14); Zuckerman (2013: pp. 206-207). According to J. HowardJohnston (2010: p. 248), this anonymous source could be the second continuation of the chronicle of John of Antioch. 


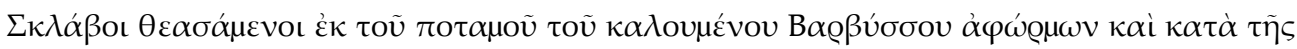

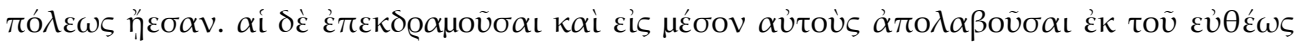

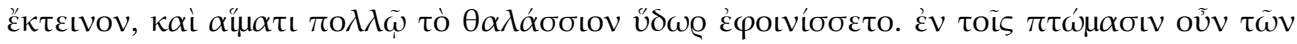

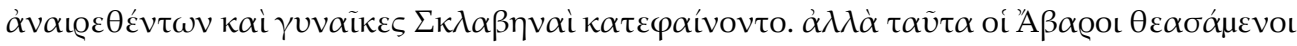

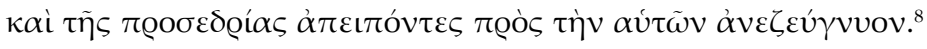

\section{The "intelligence" of Bonos}

The introduction to the passage describing the decisive attack is seemingly logical and it would fit in the events of the last day of siege. The Slavs agreed on a common signal with the Avars before the final day of the siege. However, Nikephoros literally says that the Avars gave the Slavs a sign or signal, which does not sound very logical. It seems the chronicler is either excerpting his source, or has problems with its reading. In other words, the joint plan of the Slavs and the Avars had firstly to be discussed and then only followed by its form, i.e. signal fire. ${ }^{9}$

Even the second piece of information that the Slavs set out from the river called Barbyses corresponds to reality, because the ancient geographers and Byzantine authors, when they mentioned its estuary, did not mean the actual mouth but a place where the fresh waters of the rivers Barbyses and Kydaros (Cydares) are mingled with salty waters of the Golden Horn. This location is much closer to Constantinople, approximately one kilometer from the wall of Blachernae. ${ }^{10}$ The source or rather Nikephoros himself then identified this wall as Pteron (literally "the Wing"). This part of the fortification has long been linked to the remains of the wall, which Meyer-Plath \& Schneider call the Zweifronten-Wehrgang, located between the towers of the Emperor Theophilos (16 and 18) with embrasures on both sides. ${ }^{11}$ Recently, however, based on the latest archaeological knowledge, prof. N. Asutay-Effenberger questioned the generally accepted thesis that the Theodosian walls stretched from the today's Tekfur Saray Palace northward and ended in Blachernae. Asutay-Effenberger thinks that this line must have originally run northeast and end somewhere in vicinity of the Church of St. Demetrios ó Kavó $\beta \eta \varsigma$ where the remains of the transverse wall are located to this day. In Asutay-Effenberger's view, the Pteron had to be located exactly here. ${ }^{12}$

Asutay-Effenberger further assumes that Blachernae were not protected by a wall from the land at the time of the Avar attack. Her claim is, inter alia, based on the report of the well-informed Prokopios of Caesarea who notes in De Aedificiis that at the time of its compilation, the Constantinople churches Pege and Blachernae were not protected by a wall. ${ }^{13}$

\footnotetext{
$8 \quad$ Nikeph. (1990, c. 13, pp. 59.19-60.37).

9 Speck (1988: pp. 300-301).

10 Hurbanič (2012: pp. 15-24).

11 Meyer-Plath \& Schneider (1943: pp. 102-104, 118); Müller-Wiener (1977: p. 301); Tsangadas (1980: p. 29).

12 Asutay-Effenberger (2007: pp. 15-27).

13 Prok. (1964: I. 3, 21.9-14).
} 
However, did such a claim also apply to the first half of the $7^{\text {th }}$ century, i.e. to the period of the Avar siege in 626? In this regard, I will only focus on some of the sources dealing with the topography of the area during the Avar attack. The existence of the transverse wall, which protected the Blachernae suburb with the adjacent Church of Theotokos from the land (but not from the sea) is not confirmed just by the anonymous source preserved in Nikephoros' Historia Syntomos. What is crucial in this regard is the official report of the Avar siege in Chronicon Paschale. According to that, the Armenian units conducted a skirmish during the final attack of the city and they "came out from the wall of Blachernae" and burnt the unprotected suburb in the vicinity of the Church of St. Nicholas. The church was situated in front of the current line of the Blachernae fortifications and later it was protected by a wall built by Emperor Leo V. ${ }^{14}$

Another decisive fact is the defensive position of the Constantinople ships in the Golden Horn, which began at the Church of St. Nicholas and ran to the Church of St. Conon on the opposite side of the Bay. ${ }^{15}$ As pointed out elsewhere, the Roman vessels were probably joined together and formed a firm defence line of the city. This sort of "sea wall" was the most effective defence against the flank attack of the monoxyla but it had to be attached to some other fortified places. ${ }^{16}$

But let us return to Nikephoros' version of the Avar siege. According to that, Bonos' stratagem consisted in preparation of the fleet and in the subsequent confusion of the enemy after issuing the false signal. Of course, such form of military communication was not unusual, and it is documented in the case of the Avars and the Persians before the beginning of the siege. ${ }^{17}$ However, in the context of Nikephoros' report, we should question the significance of the stratagem, in which the fire was ignited prematurely. On one hand, a logical explanation would be that the Slavs headed out to battle earlier, without the support of the Avars, which could subsequently weaken the attack. Of course, such possibility cannot be ruled out although it is not corroborated in other sources. On the other hand, the way Nikephoros explains the other part of Bonos' plan, raises a whole lot of questions, which must be taken into account in the overall analysis of the report. Nikephoros states that when the magister learned of the joint action of the Avars and the Slavs, he let the biremes and triremes land where the signal was given. ${ }^{18}$ From a formal point of view, that again poses a problem because the Avars had not given any battle signal to the Slavs yet. Nikephoros does not clarify why Bonos resorted to such an arrangement.

Moreover, Nikephoros does state that Bonos lit the false signal fires on the opposite side of the Golden Horn - apparently to confuse the Slavs. What could have been the

14 Majeska (1984: pp. 337-338); see also Speck (1986: p. 222, n. 59). However, it is not certain whether the church can be identified with the Church of St. Priskos and Nicholas mentioned by Prokopios of Kaisareia. Cf. Prok. (1964: I.6.). Majeska (1984: p. 338) supports this view, while Philippides and Hanak (Philippides \& Hanak 2011: p. 352) are more skeptical on this issue.

15 Chron. pasch. (1832: p. 721.1-3).

16 Cf. Hurbanič (2015: pp. 211-220).

17 Chron. pasch. (1832: p. 718.2-4); Theod. Synk. (1900: p. 304.31-35) = Makk (1975: p. 80).

18 In this regard, see Speck (1980: p. 92, n. 106; 1988: p. 311). The criticism of Van Dieten (1985: p. 169) is not grounded in this case. 
aim of this maneuver? If the monoxyla crews agreed on a signal with the Avars at the wall of Blachernae, of what importance was the fire lit by the defenders on the opposite side? The purpose of such "trick" in accordance with Nikephoros' version of the events is that the false signal was meant to confuse the Slavs and make them launch the attack at the wrong time and place to eventually fall into the trap of the Roman ships.

Only a few authors attempted a more detailed explanation of this part of Nikephoros' report. A. Stratos mistakenly assumed that the naval attack in the Golden Horn could have been only a diversion to make the boats of the defenders busy and allow the transport of Persian reinforcements across the Bosphorus. In this regard, however, he asked why Bonos rushed to attack the enemy if the attack was expected and awaited. Stratos tried to explain the contradiction in accordance with his assumption about the combined attack of the Slavs from the Golden Horn and Bosphorus. ${ }^{19}$

Another author, B. Tsangadas, talks about a joint and simultaneous attack of the Avars and Slavs during the decisive day of the siege, but again, he holds the naval attack in the Golden Horn to be of secondary importance. In his view, it could have been only a cover maneuver to draw attention away from the main Avar attack on the central part of the Theodosian walls. Such assumption is, however, quite unproven since all contemporary documents confirm the concentration of the Avar forces in the Blachernae and not in the Mesoteichion. Tsangadas subsequently attempted to clarify the magisters' measures in accordance with the text of Nikephoros' report. In his view, Bonos divided his fleet into two parts; one was left in the Blachernae area while the other was moved to the opposite coast of the Golden Horn. These groups were subsequently instructed to issue a false signal at the time, which was convenient to the Byzantines. Tsangadas does not explain what the essence of such convenience was. According to him, the ships of the defenders concentrated on both ends of the Golden Horn formed a kind of a trap to surround and subsequently destroy the Slavic monoxylas. ${ }^{20}$ However, Tsangadas failed to clarify the position of the ships of the Constantinople defense at the beginning of the attack, which filled the entire Golden Horn. In his plans for the final attack, the khagan had to count with the position of these ships, which represented a kind of defensive barrier - otherwise, their position would have made no sense. The possibility of an unexpected skirmish and encirclement of the monoxylas, as presented by Tsangadas in accordance with the diction of Nikephoros' report, can therefore be ruled out. Even if we admitted that Bonos withdrew the ships from that position and moved them deeper into the mouth of the Golden Horn, such move could not have escaped the attention of the Avars, who must have had a good view of that part of the city from the north shore of the Golden Horn and from other places. What is more, Bonos would have risked an attack of the vulnerable coast, which might have ended up fatally.

J. L. Van Dieten was another author who attempted a logical explanation of this part of Nikephoros' report. In his view, the Slavs, after leaving the estuary of the Barbyses, could not have exactly recognized that the agreed signal was burning on the wrong side

19 Stratos (1968: pp. 189-190).

20 Tsangadas (1980: pp. 94-95). 
of the Golden Horn. After reaching the other side, they realized that they had made a mistake and the second fire on the opposite side of the Golden Horn must have seemed like a rescue for them. ${ }^{21}$

The problem, however is, that the Slavs did not sail out of the actual estuary of the Barbyses, but, as we have already stated, from a location much closer to the Byzantine capital. The Roman ships and the Slavic monoxyla could see each other. Moreover, the contemporary documents about the Avar attack suggest one important issue in this regard. On the decisive day of the attack in the Golden Horn, the ships of the Slavs did not attack separately, but in a closed formation. The monoxyla were beyond doubt bound together, but it is questionable whether the positions of the defenders were approached by several monoxyla tied together, creating something like a catamaran or a raft, or the monoxyla were joined together on the sides, filling the entire width of the Golden Horn. ${ }^{22}$ Taking note of the testimonies, we can hardly assume that the Slavic fleet of the bound monoxyla with limited maneuverability could cruise the waters of the Golden Horn Bay back and forth and let itself be fooled by the fire burning on the opposite side even in bad weather.

Nikephoros presented the naval attack of the Slavs as a surprising move by the khagan. In reality, Bonos must have expected it since the early days of the siege. The Constantinople ships created a defensive line and assumed a permanent position right at the beginning of the siege and not on the decisive day of the attack. After all, a similar thing is suggested in the very text of Nikephoros, which says that Bonos joined ( $\alpha$ Q $\mu$ ó $\sigma \alpha \varsigma$ ) the dieres and trieres and armed them. ${ }^{23}$

The position of these ships was not random and it must have been linked to the already existing fortifications in Constantinople. The Roman ships of the defenders called skaphokaraboi were prepared for the attack and the only way the monoxyla could have succeeded was to penetrate their ranks. ${ }^{24}$

The eyewitnesses of the siege knew nothing of the "intelligence" of magister Bonos. Such silence is slightly surprising although it could be explained by the genres used by the authors such as Synkellos and Pisides. The main problem in verifying Nikephoros' story is that the official report on the siege preserved in the Chronicon Paschale has a gap at this very place. At the end of this section it is said that the Slavs were confused by the fire lit by the Armenian defenders of Constantinople in front of the wall of Blachernae. ${ }^{25}$ However, that fire cannot in any way be linked with the signal mentioned by Nikephoros,

21 Van Dieten (1985: pp. 170-171).

22 In this context, cf. the eyewitness testimony of the attack by Theod. Synk. (1900: p. 308.8-9) = Makk (1975: p. 84); Georg. Pisid. (Pertusi 1959: p. 196, v. 446-447; Targaglia 1998: p. 184, v. 446-447). See also Hošek

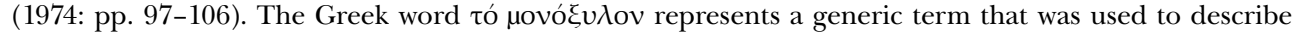
various types of such vessels. On the problem of interpretation of this term in Byzantine texts, see Орачев (1982: pp. 101-109, esp. 103-107); Strässle (1990: pp. 93-106, esp. 94-97); Havlíková (1991: pp. 89-104, esp. 94-97).

23 Cf. Hurbanič (2015: pp. 216-217).

24 On „skaphokaraboi“ cf. Hurbanič (2015: pp. 212-213, n. 6).

25 Chron. pasch. (1832: p. 724.11-15). A skeptical view of the Nikephoros' report was also assumed by Pohl (1988: pp. 253, 428, n. 53). In his view, the Slavs would have been fooled twice in the exactly same way. 
which was agreed between the Slavs and the Avars since it is obvious that the Armenian units started their skirmish only after the destruction of the naval attack of the Slavic monoxyla. In other words, they attacked and burnt the area only after the danger of the flanking attack of the Slavs and their landing on the unprotected shore of the Golden Horn passed away. This was perhaps not an intended move by the defenders, but ultimately it meant the destruction of the remaining Slavs, who managed to swim to the nearby shore. This action could have therefore become the original core of the report, which in the form of a legend was later preserved by Patriarch Nikephoros.

\section{Summary}

According to the official report preserved in Chronicon Paschale, the Avar khagan tried to use the monoxyla against Constantinople already at the very beginning of the siege. However, magister Bonos expected this attack and ordered the creation of a preventive defense line, which relied on the existing fortifications in Blachernae and the outskirts of Sykai. On the third day of the battle, however, the khagan launched the monoxyla under the St. Kallinikos Bridge, which was located approximately one kilometer from the Blachernae walls. From this position, the monoxyla could not have posed a threat to the defense of the city, but the Roman ships could not have destroyed the Slavic boats because the water was shallower at this location. It is therefore clear that the defense of Constantinople led by Bonos counted with the danger of a combined attack from the beginning of the siege and duly prepared for it.

As far as the anonymous report preserved by Nikephoros is concerned, it cannot be automatically regarded as a supplement to the official report on the Avar siege presented in the Chronicon Paschale. Although it contains a number of details, which are, in principle, in agreement with the contemporary reports about the siege, the element of stratagem and the way the measures implemented by magister Bonos throughout the naval attack of the Slavic monoxyla are further described, are highly questionable and probably belong to the category of "garbled memory" of the Avar siege.

\section{Abbreviations}

Chron. Brux. Cumont, F. (Ed.). (1894). Anecdota Bruxellensia, I: Chroniques byzantines du manuscrit 11376. Gand: Engelcke.

Chron. pasch. Dindorf, L. (Ed.). (1832). Chronicon paschale (Vol. 1; Corpus scriptorum historiae Byzantinae, 16). Bonn: Weber.

Targaglia, L. (Ed.). (1998). Carmi di Giorgio di Pisidia. Torino: Unione Tipogr.

Const. Manass. Lampsides, O. (Ed.). (1996). Constantini Manassis Breviarium chronicum (Corpus fontium historiae Byzantinae, 36). Athens: Academy.

Georg. Kedr. Bekker, I. (Ed.). (1838). Georgius Cedrenus: Compendium historiarum. 
In Georgius Cedrenus Ioannis Scylitzae ope (Vol. I; Corpus scriptorum historiae Byzantinae, 32). Bonn: Weber.

Georg. Mon. $\quad$ De Boor, C. (Ed.). (1904). Georgii Monachi Chronicon (Vol. II). Leipzig: Teubner.

Georg. Pisid. Pertusi, A. (Ed.). (1959). Georgios Pisides: Bellum avaricum. In Giorgio di Pisidia. Poemi, I: Panegirici epici (Studia patristica et Byzantina, 7). Ettal: Buch-Kunstverlag.

Jo. Zon. Büttner-Wobst, T. (Ed.). (1897). Ioannis Zonarae Epitome Historiarum. (Corpus scriptorum historiae Byzantinae, 31). Bonn: Weber.

Nikeph. Mango, C. (Ed.). (1990). Nikephoros Patriarch of Constantinople Short History (Corpus fontium historiae Byzantinae, 13). Washington D.C.: Dumbarton Oaks.

Prok. Haury, J., \& Wirth, G. (Eds.). (1964). Procopius: Peri ktismaton libri VI sive De aedificiis cum duobus indicibus. Leipzig: Teubner.

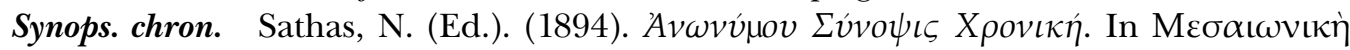

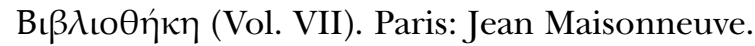

Sym. Logoth. Wahlgren, S. (Ed.). (2006). Symeonis Magistri et Logothetae Chronicon (Corpus fontium historiae Byzantinae - Series Berolinensis, 44). Berlin: De Gruyter.

Theod. Skut. Tocci, R. (Ed.). (2015). Theodori Scutariotae Chronica (Corpus fontium historiae Byzantinae - Series Berolinensis, 46). Berlin: De Gruyter.

Theod. Synk. Sternbach, L. (Ed.). (1900). Theodoros Synkellos: De obsidione Constantinopolis homilia. In Idem, Analecta Avarica (Rozprawy akademii umiejętności, Wydział filologiczny, Ser. II., Vol. XV; pp. 298-334). Cracoviae: Acad. Litterarum.

Theoph. De Boor, C. (Ed.). (1883). Theophanis Chronographia (Vol. 1). Leipzig: Teubner.

\section{Bibliography}

\section{Primary sources}

Bekker, I. (Ed.). (1838). Georgius Cedrenus: Compendium historiarum. In Georgius Cedrenus Ioannis Scylitzae ope (Vol. I; Corpus scriptorum historiae Byzantinae, 32). Bonn: Weber.

Büttner-Wobst, T. (Ed.). (1897). Ioannis Zonarae Epitome Historiarum (Corpus scriptorum historiae Byzantinae, 31). Bonn: Weber.

Cumont, F. (Ed.). (1894). Anecdota Bruxellensia, I: Chroniques byzantines du manuscrit 11376. Gand: Engelcke.

De Boor, C. (Ed.). (1883). Theophanis Chronographia (Vol. 1). Leipzig: Teubner.

De Boor, C. (Ed.). (1904). Georgii Monachi Chronicon (Vol. II). Leipzig: Teubner.

Dindorf, L. (Ed.). (1832). Chronicon paschale (Vol. 1; Corpus scriptorum historiae Byzantinae, 16). Bonn: Weber. 
Haury, J., \& Wirth, G. (Eds.). (1964). Procopius: Peri ktismaton libri VI sive De aedificiis cum duobus indicibus. Leipzig: Teubner.

Lampsides, O. (Ed.). (1996). Constantini Manassis Breviarium chronicum (Corpus fontium historiae Byzantinae, 36). Athens: Academy.

Makk, F. (Ed.). (1975). Traduction et commentaire de l'homélie écrite probablement par Théodore le Syncelle sur le siège de Constantinople en 626 (Opuscula Byzantina, III. Acta antiqua et archeologica, XIX). Szeged: Universitas de Attilla József nominata.

Mango, C. (Ed.). (1990). Nikephoros Patriarch of Constantinople Short History (Corpus fontium historiae Byzantinae, 13). Washington D.C.: Dumbarton Oaks.

Pertusi, A. (Ed.). (1959). Georgios Pisides: Bellum avaricum. In Giorgio di Pisidia. Poemi, I: Panegirici epici (Studia patristica et Byzantina, 7). Ettal: Buch-Kunstverlag.

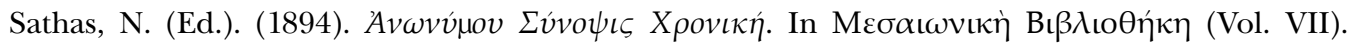
Paris: Jean Maisonneuve.

Sternbach, L. (Ed.). (1900). Theodoros Synkellos: De obsidione Constantinopolis homilia. In Idem, Analecta Avarica (Rozprawy akademii umiejętności, Wydział filologiczny, Ser. II., Vol. XV; pp. 298-334). Cracoviae: Acad. Litterarum.

Targaglia, L. (Ed.). (1998). Carmi di Giorgio di Pisidia. Torino: Unione Tipogr.

Tocci, R. (Ed.). (2015). Theodori Scutariotae Chronica (Corpus fontium historiae Byzantinae - Series Berolinensis, 46). Berlin: De Gruyter.

Wahlgren, S. (Ed.). (2006). Symeonis Magistri et Logothetae Chronicon (Corpus fontium historiae Byzantinae - Series Berolinensis, 44). Berlin: De Gruyter.

\section{Secondary sources}

Asutay-Effenberger, N. (2007). Die Landmauer von Konstantinopel-Istanbul. Historisch-topographische und baugeschichtliche Untersuchungen. Berlin - New York: De Gruyter.

Barišić, F. (1954). Le siège de Constantinople par les Avares et les Slaves. Byzantion, 24, 371-395.

Боровский, Я. Е. (1988). Византийские, старославянские и старогрузинские источники о походе русов в VII в. на Царьград. In Тимощук, Б. А. (Ed.), Древности славян и Руси (pp. 114119). Москва: Наука.

Csiky, G. (2012). Konstantinápoly városfalai és a 626. évi avar Ostrom. In P. Kiss, \& F. Piti (Eds.), Középkortörténeti tanulmányok 7 (pp. 165-183). Szeged: Gy. Szabados.

Чичуров, И. С. (1980). Византийские исторические сочинения: «Хронография» Феофана, «Бревиарий» Никифора. Тексты, перевод, комментарий. Москва: Наука.

Grumel, V. (1964). La défense maritime de Constantinople du côté de la Corne d'Or et le siège des Avares. Byzantinoslavica, 25, 217-233.

Havlíková, L. (1979). Obléhání Konstantinopole roku 626 ve světle byzantsko-íránských vztahů. Časopis Matice Moravské, 98(1-2), 126-136.

Havlíková, L. (1991). Slavic Ships in 5th-12th Centuries Byzantine Historiography. Byzantinoslavica, 51, 89-104.

Hošek, R. (1974). Slawische Schiffe bei Konstantinopolis i. J. 626. In Les études balkaniques tchécoslovaques V. (pp. 97-106). Prague: Univerzita Karlova. 
Howard-Johnston, J. (1995). The Siege of Constantinople in 626. In C. Mango, \& G. Dagron (Eds.), Constantinople and its Hinterland. Papers from the Twenty-Seventh Spring Symposium of Byzantine Studies, Oxford, April 1993 (pp. 131-145). Aldershot: Ashgate.

Howard-Johnston, J. (2010). Witnesses to a World Crisis: Historians and Histories of the Middle East in the Seventh Century. Oxford - New York: Oxford University Press.

Hunger, H. (1978). Hochsprachliche profane Literatur der Byzantiner (Vol. 1). München: C. H. Beck.

Hurbanič, M. (2009). Posledná vojna antiky. Avarský útok na Konštantínopol roku 626 vistorických súvislostiach. Prešov: Michal Vaško.

Hurbanič, M. (2010). História a mýtus. Avarský útok na Konštantínopol v roku 626 v legendách. Prešov: Michal Vaško.

Hurbanič, M. (2012). A Topographical Note Concerning the Avar Siege of Constantinople: the Question of the Localization of St. Callinicus Bridge. Byzantinoslavica, 70, 15-24.

Hurbanič, M. (2015). A Neglected Note to the Naval Defense of Constantinople during the Avar

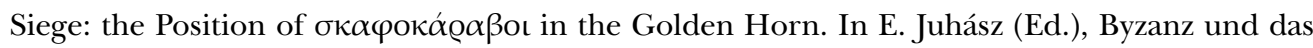
Abendland / Byzance et l'Occident (Vol. III; pp. 211-220). Budapest: Elte.

Hurbanič, M. (2016). Konstantinopol 626. Historia a legenda. Praha: Academia.

Kaegi, W. (2003). Heraclius - Emperor of Byzantium. Cambridge: Cambridge University Press.

Kaçar. T. (2017). Constantinopolis Önlerinde Avarlar ve Sâsâniler, MS 626. In M. Arslan, \& T. Kaçar (Eds.), Byzantion'dan Constantinopolis'e Istanbul Kuşatmalar (pp. 171-200). İstanbul: İstanbul Araştırmaları Enstitüsü.

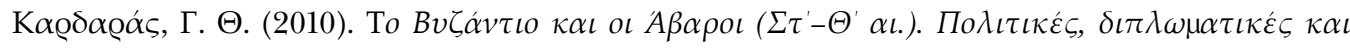

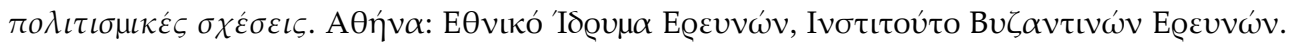

Majeska, G. (1984). Russian Travelers to Constantinople in the Fourteenth and Fifteenth Centuries (Dumbarton Oaks Studies, 19). Washington, D.C.: Dumbarton Oaks Research Library and Collection.

Mango, C. (1986). The Breviarium of the Patriarch Nikephoros. In N. Stratos (Ed.), Byzance. Hommage à A. N. Stratos (Vol. II; pp. 539-552). Athens: N. Stratos.

Meyer-Plath, B., \& Schneider, A. M. (1943). Die Landmauer von Konstantinopel. Berlin: De Gruyter.

Moravcsik, Gy. (1956). Byzantinoturcica, I: Die byzantinischen Quellen der Geschichte der Türkvölker. Berlin: Akademie-Verlag.

Müller-Wiener, W. (1977). Bildlexikon zur Topographie Istanbuls. Byzantion, Konstantinupolis, Istanbul bis zum Beginn des 17. Jahrhundert. Tübingen: Wasmuth.

Орачев, А. (1982). Морското бойно майсторство на славяни и прабългари. Palaeobulgarica/ Старобългаристика, 6, 101-109.

Pernice, A. (1905). L'imperatore Eraclio. Saggio di storia bizantina. Firenze: Tip. Galletti e Cocci.

Philippides, M., \& Hanak, W. (2011). The Siege and the Fall of Constantinople in 1453: Historiography, Topography, and Military Studies. Farnham - Burlington, VT: Ashgate.

Pohl, W. (1988). Die Awaren. Ein Steppenvolk in Mitteleuropa 567-822. München: C. H. Beck.

Soto Chica, J. (2006). Constantinopla ciudad sitiada. A.D. 626. In E. Motos Guirano, \& M. Morfakides

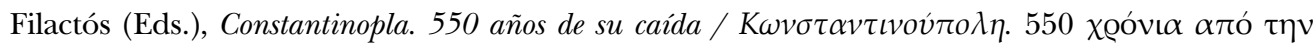
$\alpha ́ \lambda \omega \sigma \eta$ (Vol. I; pp. 111-134). Granada: Centro de Estudios Bizantinos, Neogriegos y Chipriotas.

Speck, P. (1980). Zufälliges zum Bellum avaricum des Georgios Pisides (Miscellanea Byzantina Monacensia, XXIV). München: Institut für Byzantinistik, Neugriechische Philologie und Byzantinische Kunstgeschichte der Universität. 
Speck, P. (1986). Klassizismus im achten Jahrhundert? Die Homelie [sic] des Patriarchen Germanos über die Rettung Konstantinopels. Révue des études byzantines, 44, 209-227.

Speck, P. (1987). Die Interpretation des Bellum Avaricum und der Kater Mechlempé. In Poikila byzantina (Vol. 6; pp. 371-402). Bonn: Habelt.

Speck, P. (1988). Das geteilte Dossier: Beobachtungen zu den Nachrichten über die Regierung des Kaisers Herakleios und die seiner Söhne bei Theophanes und Nikephoros (Poikila Byzantina, 9). Berlin: Habelt.

Stratos, A. N. (1967). The Avars' Attack on Byzantium in the Year 626. In P. Wirth (Ed.), Polychordia. Festschrift Franz Dölger zum 75. Geburtstag (Byzantinische Forschungen, 2; pp. 370-376). Amsterdam: Hakkert.

Stratos, A. N. (1968). Byzantium in the Seventh Century (Vol. I). Amsterdam: Hakkert.

Strässle, P. M. (1990). „To monoxylon“ in Konstantin VII. Porphyrogennetos’ Werk „De administrando Imperio“. Études balkaniques, 26, 93-106.

Szádeczky-Kardoss, S. (1998). Az avar történelem forrásai 557-tól 806-ig. Budapest: Balassi Kiadó.

Tsangadas, B. C. P. (1980). Fortifications and Defense of Constantinople (East European Monographs, 71). New York: Columbia University Press.

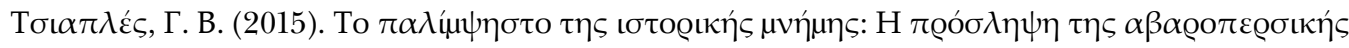

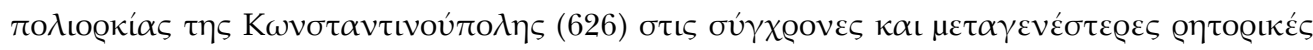

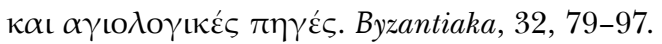

Van Dieten, J. (1985). Zum Bellum avaricum des Georgios Pisides. Bemerkungen zu einer Studie von Paul Speck. Byzantinische Forschungen, 9, 149-178.

Waldmüller, L. (1976). Die ersten Begegnungen der Slawen mit dem Christentum und den christlichen Völkern vom VI. bis VIII. Jahrhundert. Amsterdam: Hakkert.

Zuckerman, C. (2013). Heraclius and the Return of the Holy Cross. In C. Zuckerman (Ed.), Constructing the Seventh Century (Travaux et mémoires, 17; pp. 198-218). Paris: Association des Amis du Centre d'Histoire et Civilisation de Byzance.

Doc. Mgr. Martin Hurbanič, PhD. / martin.hurbanic@uniba.sk

Department of General History

Comenius University, Faculty of Arts

Šafárikovo nám. 6, 818 06, Bratislava, Slovakia 